\begin{tabular}{|c|c|c|}
\hline 」 & $\begin{array}{l}\text { International Journal of Current Research in } \\
\text { Biosciences and Plant Biology }\end{array}$ & $m$ \\
\hline & Volume 6 • Number 10 (October-2019) • ISSN: 2349-8080 (Online) & \\
\hline $\begin{array}{l}\text { EXCELLENT } \\
\text { PUBLISHERS }\end{array}$ & Journal homepage: $\underline{w w w . i j c r b p . c o m}$ & \\
\hline
\end{tabular}

\title{
Some new combinations and new names for Flora of India
}

\author{
R. Kottaimuthu ${ }^{1 *}$, M. Jothi Basu² and N. Karmegam 3 \\ 'Department of Botany, Alagappa University, Karaikudi-630 003, Tamil Nadu, India \\ ${ }^{2}$ Department of Botany (DDE), Alagappa University, Karaikudi-630 003, Tamil Nadu, India \\ 3Department of Botany, Government Arts College (Autonomous), Salem-636 007, Tamil Nadu, India \\ *Corresponding author; e-mail: kottaimuthu@yahoo.co.in
}

\begin{tabular}{ll}
\hline Article Info & ABSTRACT \\
\hline $\begin{array}{l}\text { Date of Acceptance: } \\
\text { 17 August 2019 }\end{array}$ & $\begin{array}{l}\text { During the verification of nomenclature in connection with the preparation of } \\
\text { 'Supplement to Florae Indicae Enumeratio' and 'Flora of Tamil Nadu', the authors } \\
\text { came across a number of names that need to be updated in accordance with the } \\
\text { changing generic concepts. Accordingly the required new names and new combinations } \\
\text { Date of Publication: }\end{array}$ \\
\begin{tabular}{l} 
are proposed here for the 50 taxa belonging to 17 families. \\
\hline
\end{tabular}
\end{tabular}

\section{Keywords}

Combination novum

Indian flora

Nomen novum

Tamil Nadu

\section{Introduction}

India is the seventh largest country in the world, and is home to 18,948 species of flowering plants (Karthikeyan, 2018), of which 4,303 taxa are endemic (Singh et al., 2015). During the preparation of 'Supplement to Florae Indicae Enumeratio' and 'Flora of Tamil Nadu', we came to know that several angiosperms described from various parts of India need new combinations and new names that are dealt hereunder in their respective families.

\section{Taxonomic treatment}

\section{ACANTHACEAE}

Andrographis longipedunculata (Sreem.) L.H.Cramer ex Gnanasek. \& Kottaim., comb. nov. Basionym: Neesiella longipedunculata Sreem. in Phytologia 15: 271. 1967.

Distribution: INDIA (Andhra Pradesh, Karnataka, Kerala, Maharashtra, Odisha, Rajasthan, West Bengal \& Tamil Nadu) and MYANMAR. 
Note: Cramer (1996) transferred Indoneesiella longipedunculata to Andrographis and proposed new combination $A$. longipedunculata (Sreem.) L.H.Cramer. However his new combination is invalid due to indirect basionym ref. contrary to Art. 41.5 ICN (Turland et al., 2018) and thus the combination need to be validated. Here correct reference for the basionym is given to validate the combination.

Justicia gracilis (Wight) T.Anderson var. saldanhae (Mascar. \& Janarth.) Kottaim., comb. nov.

Basionym: Rungia linifolia Nees

var. saldanhae Mascar. \& Janarth. in Novon 20(2): 182. 2010.

Distribution: INDIA (Karnataka \& Tamil Nadu).

Note: Following Vollesen (2010), Wood (2014) transferred the Indian species of Rungia under Justicia. While doing so, he proposed Justicia heyneana as a replacement name for Rungia linifolia Nees. However, he overlooked the fact that the next available name Justicia gracilis (Wight) T.Anderson is not a later homonym of Justicia gracilis Lyall ex Nees (1847) because the latter name is an invalid name when published (pro synonymo).

\section{APOCYNACEAE}

Note: As a result of recent molecular phylogenetic studies (Bruyns et al., 2014 2015), generic circumscription of Ceropegia has undergone tremendous changes (Bruyns et al., 2017, 2018a, b). The suggestion by Bruyns et al. (2017) to include all species of Brachystelma in Ceropegia is accepted by Endress et al. (2018) and POWO (2019). Hence, the following 21 new combinations and two new names are needed to reflect the current inclusion of Caralluma R. Br. and Brachystelma R.Br. in Ceropegia L.

Ceropegia adscendens (Roxb.) Bruyns var. bicolor (V.S. Ramac., S. Joseph, H. A. John \& Sofiya) Kottaim., comb. et stat nov. Basionym: Caralluma bicolor V.S. Ramac., S. Joseph, H. A. John \& Sofiya in Nordic J. Bot. 29(4): 447. 2011.
Distribution: INDIA (Kerala \& Tamil Nadu), Endemic.

Ceropegia adscendens (Roxb.) Bruyns var. carinata (Gravely \& Mayur.) Kottaim., comb. nov.

Basionym: Caralluma adscendens (Roxb.) Haw. var. carinata Gravely \& Mayur. in Bull. Madras Gov. Mus. n.s., 4(1): 16. 1931.

Distribution: INDIA (Tamil Nadu).

Note: Gravely and Mayurnathan (1931) while revising the genus Caralluma for India; they recognized 6 varieties under Caralluma adscendens. Bruyns et al. (2018) have merged all the varieties of Carallum adscendens under Ceropegia adscendens without providing any reasons. However, most of them show consistent morphological and floral variations and deserve distinct rank. Interestingly many of the workers accepted the varieties proposed by Gravely \& Mayurnathan (1931) and recognized in several works (Albers and Meve, 2002; Gilbert, 1990; Jagtap and Singh, 1999; Karuppusamy et al., 2013; Meve and Liede, 2002; Plowes, 1995; POWO, 2019; Gandhi, 1999; Singh et al., 2015). C. adscendens var. carinata is one of the most beautiful and distinct variant. It can be easily distinguished from its allies by its pendulous flower and unbranched stem.

\section{Ceropegia muruganii Kottaim., nom. nov.}

Replaced synonym: Caralluma adscendens var. geniculata Gravely \& Mayur. in Bull. Madras Gov. Mus. n.s., 4(1): 16. 1931., non Ceropegia geniculata R.A.Dyer in Bothalia 12: 631. 1979.

Etymology: The specific epithet is named to honor Dr. C. Murugan, Botanical Survey of India, Southern Regional Centre, Coimbatore, for his remarkable contributions to the Flora of Tamil Nadu.

Distribution: INDIA (Tamil Nadu).

Note: According to the latest taxonomical approach, Caralluma adscendens var. geniculata Gravely \& Mayur. is considered to be a distinct species, namely Caralluma geniculata, which differs from its allied species by its pedicel bent at 
an angle just below the flower (Karuppusamy et al., 2013; Meve and Liede, 2002; POWO, 2019). When Caralluma geniculata (Gravely \& Mayur.) Meve \& Liede is transferred to Ceropegia, the epithet is occupied by Dyer's 1979 name. Thus a new name is required, and is proposed here.

Ceropegia adscendens (Roxb.) Bruyns var. gracilis (Gravely \& Mayur.) Kottaim., comb. nov.

Basionym: Caralluma adscendens (Roxb.) Haw. var. gracilis Gravely \& Mayur. in Bull. Madras Gov. Mus. n.s., 4(1): 14. 1931.

Distribution: INDIA (Tamil Nadu).

Note: This endemic variety can be easily recognized in the field by its much branched acute stem, smaller flowers, erect slender pedicels and rotate corolla with pale expanded portion of the petals larger in proportion to the dark folded portion.

Ceropegia ananthapuramense (K.Prasad, A. Naray. \& Meve) Kottaim., comb. nov.

Basionym: Brachystelma ananthapuramense K.Prasad, A.Naray. \& Meve, Kew Bull. 73(1)-16: 1. 2018.

Distribution: INDIA (Andhra Pradesh).

Ceropegia annamacharyae (K. Prasad, Prasanna, Meve, Sankara Rao \& T. Thulasaiah) Kottaim., comb. nov.

Basionym: Brachystelma annamacharyae K. Prasad, Prasanna, Meve, Sankara Rao \& T. Thulasaiah in Nord. J. Bot. 34(3): 360. 2016.

Distribution: INDIA (Andhra Pradesh).

Ceropegia gondwanense (Govekar, Kahalkar \& Sardesai) Kottaim., comb. nov.

Basionym: Brachystelma gondwanense Govekar, Kahalkar \& Sardesai in Rheedea 26(2): 145. 2016.

Distribution: INDIA (Maharashtra).

Ceropegia gandhiana Kottaim., nom. nov.
Replaced synonym: Brachystelma maculatum Hook.f., Fl. Brit. India 4(10): 65. 1883., non Ceropegia maculata Bedd. in Madras J. Lit. Sci., ser. 3, 1: 52. 1864 .

Etymology: The specific epithet is named to honour Dr. Kanchi N. Gandhi (Senior Nomenclatural Registrar, Harvard University Herbaria, USA) for his valuable contribution in plant taxonomy and nomenclature.

Distribution: INDIA (Karnataka \& Tamil Nadu), Endemic.

Note: Bruyns et al. (2017) did not accept the specific status of Brachystelma maculata, $B$. rangacharii, $B$. penchalakonense and $B$. nallamalayanum hence they synonymized under Ceropegia bourneae (Gamble) Bruyns without ample reasons. All four species share similar habit with slender, sturdy and erect stems and long drooping leaves. However, they differ from each other by their floral characters viz., corolla colour, ornamentation, indumentum and corona structure and thus hold their specific identities (Prasad and Rao, 2013; Prasad and Venu, 2018; Pullaiah et al., 2019; Rasingam et al., 2013; Sadasivaiah et al., 2016).

The specific epithet "maculata" cannot be used in combination with Ceropegia, as it would be a later homonym of Ceropegia maculata Bedd. (1864). since it has no taxonomic synonyms, a new replacement name is proposed above in accordance with the Shenzhen code (Turland et al., 2018).

Ceropegia mahendragiriense (K.Prasad, Chorghe \& Venu) Kottaim., comb. nov.

Basionym: Brachystelma mahendragiriense K.Prasad, Chorghe \& Venu in Rheedea 27(2): 135. 2017.

Distribution: INDIA (Andhra Pradesh).

Ceropegia megamalayana (Karupp.) Kottaim., comb. nov.

Basionym: Brachystelma megamalayana Karupp. in Pull. et al., Monogr. Brachystema \& Ceropegia in India: 40. 2019. 
Distribution: INDIA (Tamil Nadu).

Ceropegia moorei (Aditya) Kottaim., comb. nov.

Basionym: Caralluma moorei Aditya in Asklepios 110: 7. 2011.

Distribution: INDIA (Odisha).

Note: Bruyns et al. (2017) have erroneously merged this species under Ceropegia stalagmifera. But Caralluma moorei can be easily distinguished in the field by its two or three flowers in axils (vs solitary flowers in C. stalagmifera), bracts linear-subulate (vs. bracts triangular in C. stalagmifera) and corolla margin tipped with needle like hairs (vs. corolla margin tipped with stalagmiferous shaped hairs in C. stalagmifera). Moreover, Karuppusamy et al. (2013), Singh et al. (2015) and POWO (2019) maintained it as distinct species under the name Caralluma moorei, and the new combination is made here for those agree with this view.

Ceropegia nallamalayanum (K. Prasad \& B. R. P. Rao) Kottaim., comb. nov.

Basionym: Brachystelma nallamalayanum K. Prasad \& B. R. P. Rao in J. Threat. Taxa 5(14): 4904. 2013.

Distribution: INDIA (Andhra Pradesh \& Telengana).

Ceropegia naorojii (P.Tetali, D.K.Kulk., S. Tetali \& M.-S.Kumbhojkar) Kottaim., comb. nov.

Basionym: Brachystelma naorojii P.Tetali, D.K.Kulk., S.Tetali \& M.-S.Kumbhojkar in Rheedea 8(1): 75. 1998.

Distribution: INDIA (Maharashtra).

Note: Bruyns et al. (2017) treated this species as a heterotypic synonym of Ceropegia malwanensis (S.R. Yadav \& N.P. Singh) Bruyns without any substantial reasons. However, most of the Indian workers treated it as an endemic species of Maharashtra (Almeida, 2001; Jagtap and Singh, 1999; Mishra and Singh, 2001; Pullaiah et al., 2019; Singh et al., 2015) and the new combination is made here for those agree with this view.
Ceropegia nigidianum (Raja Kullayisw., Sandhyar. \& Pull.) Kottaim., comb. nov.

Basionym: Brachystelma nigidianum Raja Kullayisw., Sandhyar. \& Pull. in Kew Bull. 71(4)50: 5. 2016.

Distribution: INDIA (Andhra Pradesh).

Ceropegia penchalakonense (Rasingam, Chorghe, Meve, Sankara Rao \& Prasanna)

Kottaim., comb. nov.

Basionym: Brachystelma penchalakonense Rasingam, Chorghe, Meve, Sankara Rao \& Prasanna in Kew Bull. 68(4): 663. 2013.

Distribution: INDIA (Andhra Pradesh).

Ceropegia rangacharii (Gamble) Kottaim., comb. nov.

Basionym: Brachystelma rangacharii Gamble in Bull. Misc. Inform. Kew 1922(3): 120. 1922.

Distribution: INDIA (Karnataka \& Tamil Nadu), Endemic.

Ceropegia sarkariae (Lavranos \& R.Frandsen) Bruyns var. longipedicellata (Aditya) Kottaim. comb.nov.

Basionym: Caralluma sarkariae Lavranos \& R.Frandsen var. longipedicellata Aditya in Asklepios 110: 21. 2011.

Distribution: INDIA (Tamil Nadu), Endemic.

Ceropegia seshachalamense (K. Prasad \& Prasanna) Kottaim., comb. nov.

Basionym: Brachystelma seshachalamense K.Prasad \& Prasanna in Bangladesh J. Pl. Taxon. 23(1): 53. 2016.

Distribution: INDIA (Andhra Pradesh). Ceropegia shrirangii (Kambale, Gholave \& Sardesai) Kottaim., comb. nov.

Basionym: Brachystelma shrirangii Kambale, Gholave \& Sardesai in Rheedea 26(2): 145. 2016. 
Distribution: INDIA (Maharashtra).

\section{Ceropegia truncatocoronata (Sedgw.)}

Kottaim. comb. nov.

Basionym: Boucerosia truncatocoronata Sedgw. in J. Indian Bot. 2: 125. 1921.

Distribution: INDIA (Karnataka, Maharashtra \& Tamil Nadu), Endemic.

Note: Bruyns et al. (2017) have merged this species under C. crenulata (Wallich) Bruyns. However it is distinct in its bifid corona lobes reduced to a broadly truncate top with minute horns or teeth at each end.

Ceropegia vemanae (A.M.Reddy, M.V.S.Babu \& K.Prasad) Kottaim., comb. nov.

Basionym: Brachystelma vemanae A.M.Reddy, M.V.S.Babu \& K.Prasad in Nordic J. Bot. 36(10)e02067: 2. 2018.

Distribution: INDIA (Andhra Pradesh).

Vincetoxicum balakrishnanii (P.M.Salim \& J.Mathew) Kottaim., comb. nov.

Basionym: Tylophora balakrishnanii P.M.Salim \& J.Mathew in P.M. Salim et al., NeBIO 8(3): 2017.

Distribution: INDIA (Kerala).

Note: Recent molecular phylogenetic analysis (Liede-Schumann et al., 2012, 2016) supported the reduction of Tylophora under Vincetoxicum (Liede-Schumann and Meve 2018). However two recently described species viz., Tylophora balakrishnanii P.M.Salim \& J.Mathew and Tylophora neglecta J.Mathew were never transferred hence, a necessary new combination is proposed here.

Vincetoxicum neglectum (J.Mathew) Kottaim., comb. Nov Basionym: Tylophora neglecta J.Mathew in P.M. Salim et al., NeBIO 8(3): 132. 2019.

Distribution: INDIA (Kerala).

Note: Recently, Liede-Schumann and Meve (2018) proposed a broader circumscription of Vincetoxicum [sensu lato] based on molecular phylogenetic analysis (Liede-Schumann et al., 2012, 2016). The new combination under Vincetoxicum is therefore required.

\section{ASPARAGACEAE}

Asparagus biradarii (Kamble) Kottaim., comb. nov.

Basionym: Protasparagus biradarii Kamble in J. Econ. Taxon. Bot. 17(1): 197. 1993.

Distribution: INDIA (Odisha).

Note: This species was not included in Endemic Vascular Plants of India (Singh et al., 2015). Moreover, POWO (2019) treated as an unplaced name.

\section{ASTERACEAE}

\section{Lactuca bandyopadhyana Kottaim., nom. nov.}

Replaced synonym: Lactuca pygmaea Bhellum in Current Life Sci. 1: 2. 2015, nom. illeg., non Lactuca pygmaea Zoll. \& Moritzi in NatuurGeneesk. Arch. Ned.-Indië 2: 565. 1845.

Etymology: The specific epithet is named to honour Dr. Subir Bandyopadhyay, distinguished legume expert, Botanical Survey of India for his remarkable contribution to Indian plant taxonomy.

Distribution: INDIA (Jammu \& Kashmir).

Note: A replacement name is required as the name Lactuca pygmaea has already been used by Zollinger and Moritzi (1845).

Monosis kannikattiensis (Rajakumar, Selvak., S.Murug. \& Chellap.) Kottaim., comb. nov. Basionym: Vernonia kannikattiensis Rajakumar, Selvak., S.Murug. \& Chellap. in Indian J. Forest. 38(3): 269. 2015 .

Distribution: INDIA (Tamil Nadu).

Note: Recent molecular and phylogenetic studies supported the polyphyletic nature of Vernonia 
Schreb. sensu lato (Keeley et al. 2007; Keeley and Robinson 2009; Loeuille et al. 2015). A few workers in India transferred the known species of Vernonia to the respective segregated genera (Kumar, 2014; Kottaimuthu, 2015; Punekar and Vasudeva Rao, 2006; Rasiya Beegam and Sibi, 2012). The newly described Vernonia kannikattiensis (Rajakumar et al., 2015) falls within the circumscription of Monosis. Hence the necessary new combination is presented above.

\section{CYPERACEAE}

Carex khasiana (Jana \& V.S.Kumar) Kottaim., comb. nov.

Basionym: Kobresia khasiana Jana \& V.S.Kumar in J. Jap. Bot. 92(2): 94. 2017.

Distribution: INDIA (Assam).

Note: This combination is needed to reflect the current inclusion of Kobresia in Carex (GCG, 2015).

Cyperus melanospermus (Nees) Valck. var. gudaluriensis (Wad.Khan \& R. D. Taur) Kottaim., comb. nov.

Basionym: Kyllinga melanosperma Nees var. gudaluriensis Wad.Khan \& R.D.Taur in Wad.Khan, Cyperaceae W. Ghats, W. Coast \& Maharashtra: 269. 2014.

Distribution: INDIA (Tamil Nadu).

Note: According to the recent generic concept of Cyperus (Larridon et al., 2013, 2014),

Kyllinga melanosperma var. gudaluriensis should be transferred to Cyperus and hence a new combination is made here.

Cyperus pluristamineus (Govind. \& Ramani) Kottaim., comb. nov.

Basionym: Kyllinga pluristaminea Govind. \& Ramani in J. Econ. Taxon. Bot. 18(2): 336. 1994.

Distribution: INDIA (Tamil Nadu).

Note: This combination is needed to reflect the current inclusion of Kyllinga in Cyperus (Larridon et al., 2013, 2014).

Cyperus pseudoalatus (Wad.Khan \& R.D.Taur) Kottaim., comb. nov.

Basionym: Kyllinga pseudoalata Wad.Khan \& R.D.Taur in Wad.Khan, Cyperaceae W. Ghats, W. Coast \& Maharashtra: 274. 2014.

Distribution: INDIA (Tamil Nadu).

Note: This combination is needed to reflect the current inclusion of Kyllinga in Cyperus (Larridon et al., $2013 \&$ 2014).

\section{CLEOMACEAE}

Corynandra chelidonii (L.f.) Cochrane \& Iltis var. pallae (C.S.Reddy \& V.S.Raju) Kottaim., comb. nov.

Basionym: Cleome chelidonii L.f. var. pallae C.S. Reddy \& V.S.Raju in J. Econ. Taxon. Bot. 25(1): 217. 2001.

Distribution: INDIA (Andhra Pradesh).

Note: As per the recent generic concept of Cleomaceae (Cochrane and Iltis, 2014), C. chelidonii var.pallae should be transferred to Corynandra and consequently a new combination is made here.

\section{FABACEAE}

Grona saulierei (Schindl.) Kottaim., comb. et stat. nov.

Basionym: Nicolsonia barbata (L.) DC. var. var. saulierei Schindl., Repert. Spec. Nov. Regni Veg. 23: 359. 1927.

Distribution: INDIA (Tamil Nadu), Endemic.

Note: During the studies of legumes of Dindigul District for the Ph.D. dissertation of the first author, he has located a small population of Desmodium barbatum (L.) Benth. subsp. saulieri (Schindl.) H. Ohashi in Sottimalai, Palani Hills. Critical studies with protologues and type specimens of infraspecific categories of Desmodium barbatum, it was found that the 
variety saulierei Schindl. warrant acceptance as distinct species. Hence, it is raised to species status. As per the recent generic concept of Desmodieae (Ohashi and Ohashi, 2018) a new combination is made here.

Indigofera trifoliata L. var. prostrata (Willd.) Kottaim., comb. et. stat. nov.

Basionym: Indigofera prostrata Willd., Sp. Pl. 3: 1226. 1802.

Distribution: INDIA (Andhra Pradesh, Goa, Gujarat, Himachal Pradesh, Karnataka, Kerala, Madhya Pradesh, Maharashtra, Orissa and Tamil Nadu) and BANGLADESH (Mostaph \& Uddin, 2013).

Note: Matthew (1983, 1999), Sanjappa (1995) and Chauhan and Pandey (2015) who in turn had followed Gamble (1919) in treating this taxon at a specific status. De Kort and Thijsse (1984) treated it as a synonym under Indigofera trifoliata L. The present studies at MH, RHT, and ATREE in addition to field observations, indicate that it is very difficult to segregate Indigofera prostrata from I. trifoliata. However, the former is quite distinct for its torulose pods and bilateral seeds with coarsely reticulate surface where as $I$. trifoliata has non-torulose pods and cylindrical seeds with fossulate surface. Therefore, Indigofera prostrata Willd. is reduced here as a variety under Indigofera trifoliata $\mathrm{L}$.

Solori scandens (Roxb.) Sirich. \& Adema var. saharanpurensis (Thoth.) Kottaim., comb.nov.

Basionym: Derris timorensis (DC.) Pittier var. saharanpurensis Thoth. in Bull. Bot. Surv. India 105. 1972.

Distribution: INDIA (Uttar Pradesh), Endemic (Khanna, 2001; Singh et al., 2015).

Note: This varietal combination is needed to reflect the current inclusion of Derris scandens in Solori (Sirichamorn et al., 2014).

\section{HYPOXIDACEAE}

Note: Traditionally the genus Molineria is distinguished from its allied genus Curculigo by having comparatively a smaller and unbeaked seed without an extended end in the funicle and striate testa ornamentation. Since morphologically both the genus are similar, Christenhusz \& Byng (2018) have merged the former under latter. Hence, the following two new combinations are needed to reflect the current inclusion of Molineria in Curculigo.

Curculigo garoense (D.K.Roy \& D.Vijayan) Kottaim., comb. nov.

Basionym: Molineria garoense D.K.Roy \& D.Vijayan in Pleione 10(2): 366. 2016.

Distribution: INDIA (Meghalaya).

Curculigo prainiana (Deb) Bennet \& Raizada var. josephii (D. K. Roy, D. Verma \& Talukdar) Kottaim., comb. nov.

Basionym: Molineria prainiana Deb var. josephii D. K. Roy, D. Verma \& Talukdar in J. Jap. Bot. 90(1): 61. 2015.

Distribution: INDIA (Arunachal Pradesh).

\section{LAMIACEAE}

Platostoma menthoides (L.) A. J. Paton var. longiracemosum (Ramam. \& Sebastine) Kottaim., comb. nov.

Basionym: Geniosporum prostratum (L.) Benth. var. longiracemosum Ramam. \& Sebastine in Bull. Bot. Surv. India 6: 325. 1964.

Distribution: INDIA (Tamil Nadu), Endemic.

Note: Paton (1997) while revising the genus Platostoma, he transferred Geniosporum menthoides to Platostoma as P. menthoides but overlooked the variety endemic to Tamil Nadu viz., Geniosporum prostratum var. longiracemosum Ramam. \& Sebastine. This endemic variety differs from the typical variety by its bracts deltoid, membranous, transparent at margins (bracts cordate, not membranous, not transparent, at margins in var. menthoides) and lateral calyx-teeth lanceolate, awned (lateral calyx-teeth neither lanceolate nor awned in var. menthoides). 


\section{LAURACEAE}

\section{Machilus macrantha Nees var. brevifolia} (M.Gangop.) Kottaim., comb. nov.

Basionym: Persea macrantha (Nees) Kosterm. var. brevifolia M. Gangop. in Bangladesh J. Plant

Taxon. 16(2): 144. 2009.

Distribution: INDIA (Tamil Nadu).

Note: The genus Machilus was often treated as a synonym of Persea Miller, but recent molecular evidence supports that Machilus should be treated as a distinct genus (Rohwer et al., 2009, Li et al., 2011). Hence, a new varietal combination is proposed under Machilus.

\section{LORANTHACEAE}

\section{Macrosolen pseudopsilantha (Rajasek.) Kottaim., comb. nov.}

Basionym: Elytranthe pseudopsilantha Rajasek. in J. Swamy Bot. Club 3(1-2): 15. 1986.

Distribution: INDIA (Kerala \& Tamil Nadu), Endemic.

Note: E. pseudopsilantha was described by Rajasekaran (1986) based on the collections made from Munnar and High Wavy mountain in Tamil Nadu. On critical studies from the protologue, this new species falls within the circumscription of Macrosolen (Inflorescence capitulum, subsessile, peduncles substended by 3-4 whorls of bracts; corolla lobes 6 , reflexed and coiled), and hence the new combination is provided. In the protologue, it is erroneously compared with $E$. psilantha but it is found to be allied to Macrosolen parasiticus.

\section{ORCHIDACEAE}

Bulbophyllum indicum (C.S.Kumar \& Garay) Kottaim., comb. nov.

Basionym: Rhytionanthos indicus C. S. Kumar \& Garay, Proc. 20th World Orchid Conf.: 114. 2013.

Distribution: INDIA (Kerala \& Tamil Nadu), Endemic.
Note: This combination is needed to reflect the current inclusion of Rhytionanthos in Bulbophyllum (Pridgeon et al., 2014; Vermeulen et al., 2014, 2015).

\section{Crepedium crenulatum (Ridl.) Kottaim., comb. nov.}

Basionym: Microstylis crenulata Ridl. in J. Linn. Soc., Bot. 24: 346. 1888.

Distribution:-INDIA (Tamil Nadu).

Note: On critical studies from the protologue and recent collection from Nilgiri, it is found that the species falls within the circumscription of Crepedium (Pankaj Kumar, pers. comm.) and hence the new combination is provided.

Dendrolirium ferrugineum (Lindl.) A.N.Rao var. assamicum (Gogoi, Das \& Yonzone) Kottaim., comb. nov.

Basionym: Eria ferruginea Lindl. var. assamica Gogoi, Das \& R.Yonzone in McAllen Int. Orchid Soc. J. 15(2): 5. 2014.

Distribution: INDIA (Assam).

Note: This combination is needed to reflect the current inclusion of Eria ferruginea in Dendrolirium (Sirichamorn et al., 2014).

Porpax nana (A.Rich.) Schuit., Y.P.Ng \& H.A.Pedersen var. brevilinguis (Joseph \& Chandras.) Kottaim., comb. nov.

Basionym: Eria muscicola (Lindl.) Lindl. var. brevilinguis Joseph \& Chandras. in Bull. Bot. Surv. India 15: 267. 1973.

Distribution: INDIA (Kerala \& Tamil Nadu), Endemic.

Note: The circumscription of this variety has been a matter of dispute among the orchidologists. Joseph and Chandrasekaran (1973) described this variety based on the specimens collected from the western slopes of Agasthyamalai, Kerala. This was accepted as a variety of Eria muscicola by Karthikeyan et al. (1989) and Pandey and Dwarakan (1995). However, Kumar and Manilal 
(2006) considered it as a synonym of Eria nana, while Agrawala and Chowdhery (2009) treated it as a variety of Eria nana. Bajracharya and Shrestha (2009) elevated this variety as a species. Since the diagnostic characters are distinct and constant, liberty being taken here to treat it as a variety under $P$. nana.

\section{POACEAE}

Yushania longispiculatus (R.B.Majumdar) Kottaim., comb. nov.

Basionym: Chimonocalamus longispiculatus R.B.Majumdar in S. Karthikeyan et al., Fl. Ind. Enumerat. - Monocot.: 276. 1989.

Distribution: INDIA (Arunachal Pradesh).

Note: This combination is needed to reflect the current inclusion of Chimonocalamus in Yushania (Borthakur and Sharma, 2018).

\section{RUBIACEAE}

Catunaregam brandisii (Gamble) Kottaim., comb. nov.

Basionym: Randia brandisii Gamble, Fl. Pres. Madras: 416. 1921.

Distribution: INDIA (Andhra Pradesh, Karnataka, Kerala, Mahrashtra \& Tamil Nadu).

Note: Tirvengadum (1978) incorrectly merged Randia brandisii under Catunaregam spinosa. Till now, many taxonomists in India (Sasidharan, 2013) and Kew (Govaerts, 2003; Govaerts et al., 2011; POWO, 2019; Ruhsam, 2005) agree with the views of Tirvengadam. However, as indicated by Matthew (1991, 1999) and Pallithanam (2001), Randia brandisii and $R$. dumetorum (=C. spinosa) are quite distinct species.

\section{SOLANACEAE}

Solanum violaceum Ortega var. multiflorum (Roth) Kottaim., comb. nov.

Basionym: Solanum multiflorum Roth, Syst. Veg., ed. 15 bis 4: 669. 1819.
Distribution: INDIA (Karnataka, Kerala \& Tamil Nadu), Endemic.

Note: It is not easy to find good characters to separate $S$. multiflorum from $S$. violaceum. Hence it is reduced as a variety of $S$. violaceum. The only distinguishing character between the two taxa is plant height and number of flowers in an inflorescence. Plants $<3 \mathrm{~m}$ tall and flowers $<25$ per inflorescence in var. violaceum, where as plants $>4 \mathrm{~m}$ tall and flowers $>50$ per inflorescence in var. multiflorum.

\section{SCROPHULARIACEAE}

\section{Veronica gandhii Kottaim., nom.nov.}

Replaced synonym: Veronica biloba var. minima N.C.Nair 5: 327. 1963, nom.illeg., non Veronica biloba var. minima K.Koch Linnaea 17(3): 288. 1843. Veronica minima Chandra Sek. \& S.K. Srivast., Fl. Pin Valley Natl. Park 180. 2009, nom. illeg., non Veronica minima (K.Koch) K.Koch, Linnaea 22(6): 700. 1849.

Etymology: The specific epithet is named to honour Dr. Kanchi N. Gandhi (Senior Nomenclatural Registrar, Harvard University Herbaria, USA) for his valuable contribution in plant taxonomy and nomenclature.

Distribution: INDIA (Himachal Pradesh), Endemic.

Note: This distinct entity was originally described as a variety under $V$. biloba. Later, Chandra Sekar and Srivastava (2009) elevated this variety in to species status. Unfortunately, the name $V$. minima had been previously used by Koch in 1843 , thus Veronica minima Chandra Sek. \& S.K.Srivast. is a later homonym of Veronica minima (K.Koch) K.Koch and therefore illegitimate. Hence, a new replacement name is proposed above in accordance with the Shenzhen code (Turland et al., 2018). Interestingly, Agnihotri et al. (2014) while compiling the genus Veronica for India, they neither include nor comment on the status of the taxa.

\section{VIOLACEAE}

Afrohybanthus vatsavayae (C.S.Reddy) Kottaim., comb. nov. 
Basionym: Hybanthus vatsavayae C.S.Reddy in J. Econ. Taxon. Bot. 25(1): 219. 2001.

\section{Distribution: INDIA (Andhra Pradesh).}

Note: Recent molecular phylogenetic studies on Violaceae proved that Hybanthus is polyphyletic, with species in nine morphologically and biogeographically distinct clades (Wahlert et al., 2014). Hence, Flicker and Harvey (2015) erected a new genus Afrohybanthus that can be easily distinguished from Hybanthus sensu stricto by having solitary flowers, strongly zygomorphic corollas with a well differentiated bottom petal, filaments basally connate into a short "collar" with free portions to the filaments and two staminal glands. While scrutinizing the protologue of Hybanthus vatsavayae we found that this species falls within the circumscription of Afrohybanthus, and hence the new combination is provided.

\section{Acknowledgement}

Authors are thankful to 'retd' Dr. G.V.S. Murthy, Scientist 'G', Botanical Survey of India, Southern Regional Centre for granting permission to consult the herbarium and library. The authors (RK \& MJ) thankfully acknowledge the MHRD-RUSA 2.0 [F.24/51/2014-U, Policy (TNMulti-Gen), Dept. of Edn. Govt. of India] for the financial supports and infrastructure facilities. We are thankful to Dr. S. Liede-Schumann, University of Bayreuth, Germany for literature and Dr. Pankaj Kumar, Kadoorie Farm and Botanic Garden, Hong Kong for help in identification.

\section{Conflict of interest statement}

Authors declare that they have no conflict of interest.

\section{References}

Aditya, S., 2011. Caralluma moorei Aditya sp. nova. A new species from East Coastal India. Asklepios. 110, 3-10.

Aditya, S., 2011. Caralluma sarkariae var. longipedicellata var. nova. A new Caralluma variety from Peninsular India. Asklepios. 110. 18-24.
Agnihotri, P., Dixit V., Husain, T., 2014. Conspectus of the genus Veronica Linnaeus (Plantaginaceae) in India. Pleione. 8(1), 9-16.

Agrawala, D. K., Chowdhery, H. J., 2009. On the taxonomy of some Indian species of Eria (Orchidaceae). J. Orchid Soc. India. 23, 63-69.

Albers, F., Meve, U., 2002. Illustrated Handbook of Succulent Plants: Asclepiadaceae. Springer, New York.

Almeida, M. R., 2001. Flora of Maharashtra. Vol. 3. Rubiaceae to Martyniaceae. Blatter Herbarium, Mumbai.

Bajracharya, D.M., Shrestha, K.K., 2009. Notes on Eria muscicola (Lindley) Lindley (Orchidaceae) and its allied novelties. Pleione. 3(2), 163-166.

Beddome, R. H., 1864. Contributions to the botany of Southern India. Madras J. Lit. Sci. Ser. III 1, 37-59.

Bhellum B. L., 2015. Lactuca pygmaea (Asteraceae, Cichorieae) - a new species from India. Curr Life Sci. 1(1): 1-5.

Borthakur, S. K., Sharma, T. P., 2018. Bamboos of North-East India. EBH Publishers, India.

Bruyns, P. V., Klak, C., Hanáček, P., 2014. Evolution of the stapeliads (ApocynaceaeAsclepiadoideae)-repeated major radiation across Africa in an Old World group. Mol. Phylogenet. Evol. 77, 251-263.

Bruyns, P. V., Klak, C., Hanáček, P., 2015. Recent radiation of Brachystelma and Ceropegia (Apocynaceae) across the Old World against a background of climatic change. Mol. Phylogenet. Evol. 90, 49-66.

Bruyns, P. V., Klak, C., Hanáček, P., 2018a. Corrigendum to "A revised, phylogeneticallybased concept of Ceropegia (Apocynaceae)" [S. Afr. J. Bot. 112 (2017) 399-436]. South African J. Bot. 116, 140-141.

Bruyns, P. V., Klak, C., Hanáček, P., 2018b. An account of Ceropegia sect. Chamaesiphon (Apocynaceae) in Moçambique with new records and two new species. Phytotaxa. 364(2), 111-135.

Chandra Sekar, S., Srivastava, S. K., 2014. Flora of the Pin valley National park, Himachal Pradesh. Botanical Survey of India.

Christenhusz, M. J. M., Byng, J. W., 2018. Hypoxidaceae. In: Christenhusz, M. J. M., Fay, 
M. F., Byng, J. W., (Eds.). The Global Flora: A practical flora to vascular plant species of the world. Plant Gateway Ltd. 4, 1-155.

Cochrane, T. S., Iltis, H. H., 2014. Studies in the Cleomaceae VII: Five new combinations in Corynandra, an earlier name for Arivela. Novon. 23, 21-26.

Cramer, L. H., 1996. Notes on Sri Lankan Acanthaceae. Kew Bull. 51, 553-556.

Dyer, R. A., 1979. Notes on African plants: Asclepiadaceae. Bothalia 12(4), 629-631.

Endress, M. E., Meve, U., Middleton, D. J., LiedeSchumann, S., 2018. Apocynaceae. In: Kadereit, J. W., Bittrich, V. (Eds.), The Families and Genera of Vascular Plants. XV. Flowering Plants Eudicots Apiales, Gentianales (except Rubiaceae). Springer, Berlin.

Flicker, B. J., Ballard, H. E. Jr., 2015. Afrohybanthus (Violaceae), a new genus for a distinctive and widely distributed old World hybanthoid lineage. Phytotaxa. 230 (1), 39-53.

Gandhi, R., 1999. Carallumas of the Indian Subcontinent. Indian Society of Cacti \& Succulents, New Delhi.

Gangopadhyay, M., 2009. Nine New taxa and a new combination in Lauraceae from India and Myanmar. Bangl. J. Plant Taxon. 16(2), 141149.

GCG (Global Carex Group), 2015. Making Carex monophyletic (Cyperaceae, tribe Cariceae): a new broader circumscription. Bot. J. Linn. Soc. 179, 1-42.

Gilbert, M.G., 1990. A review of Caralluma R. Br. and its segregates. Bradleya. 8, 1-32.

Gogoi, K., Das, R., Yonzone, R., 2014. Eria ferruginea Lindl var. assamica (Orchidaceae): A new variety from Assam, North East India. McAllen Int. Orchid Soc. J. 15(2), 2-11.

Govaerts, R., 2003. World Checklist of Selected Plant Families Database in ACCESS: 1-216203. The Board of Trustees of the Royal Botanic Gardens, Kew.

Govaerts, R., Andersson, L., Robbrecht, E., Bridson, D., Davis, A., Schanzer, I., Sonke, B., 2011. World checklist of Rubiaceae. Royal Botanic Gardens, Kew.

Gravely, F. H., Mayurnathan, P. V., 1931. The Indian species of genus Caralluma (Asclepiadaceae ). Bull. Madras Gov. Mus. (n.s.) Nat. Hist. 4, 1-28.

Jagtap, A. P., Singh, N. P., 1999. Asclepiadaceae \& Periplocaceae. Fasc. Fl. India. Fas. 21. Botanical Survey of India, Kolkatta.

Joseph, J., Chandrasekaran, V., 1973. Eria muscicola (Lindl.) Lindl. var. brevilinguis - A new variety of orchid from Agastyamalai, South India. Bull. Bot. Surv. India. 15, 267-269.

Kamble, S. Y., 1993. On a new species of Protasparagus from Orissa, India. J. Econ. Taxon. Bot. 17(1), 195-197.

Karthikeyan, S., 2018. Flowering plants (Angiosperms) of India-An analysis. J. Econ. Taxon. Bot. 41(1-2), 5-23.

Karthikeyan, S., Jain, S. K., Nayar, M. P., Sanjappa, M., 1989. Florae Indicae Enumeratio: Monocotyledonae. Botanical Survey of India, Calcutta.

Karthikeyan, S., Sanjappa, M., Moorthy, S., 2009. Flowering plants of India Dicotyledons, Vol. 1, Acanthaceae - Avicenniaceae. Botanical Survey of India, Kolkata.

Karuppusamy, S., 2019. Brachystelma megamalayana. In: Pullaiah, T., Karuppusamy, S., Rama Murthy, K. S., (Eds.), Monograph on Brachystelma and Ceropegia in India. CRC Press, Taylor \& Francis Group, Boca Raton.

Karuppusamy, S., Ugraiah, A., Pullaiah, T., 2013. Carallama (Sensu lato) in India: Antiobesity Plants. Regency Publications, New Delhi.

Keeley, S. C., Robinson, H., 2009. Vernonieae. In: Funk, V. A., Susana, A., Stuessy, T. F., Bayer, R. J. (Eds), Systematics, Evolution, and Biogeography of Compositae. International Association for Plant Taxonomy (IAPT), Vienna, Austria, pp. 439-469.

Keeley, S. C., Forsman, Z. H., Chan, R., 2007. A phylogeny of the "evil tribe" (Vernonieae: Compositae) reveals Old/New World long distance dispersal: Support from separate and combined congruent datasets (trnL-F, ndhF, ITS). Mol. Phylogenet. Evol. 44, 89-103.

Khanna, K. K., 2001. Endemic plants of Uttar Pradesh (Angiosperms). Phytotaxonomy. 1, 7175.

Kottaimuthu, R., 2015. Three new combinations in Acilepis D.Don (Asteraceae) from India. Telopea. 18, 375-377. 
Kullayiswamy, K. R., Sandhya Rani, S., Pullaiah, T., 2016. Brachystelma nigidianum (Apocynaceae: Asclepiadoideae), a new species from India. Kew Bull. 71(4), 1-7.

Kumar, C. S., Garay, L. A., 2013. A synopsis of the genus Rhytionanthos Garay, Hamer \& Siegerist. In: Conference Proceedings: 20th World Orchid Conference, 13-20 November 2011. National Parks Board, pp. 111-123.

Kumar, E. S. S., 2014. A new combination in Baccaroides Moench (Asteraceae) from India. J. Sci. Res. 6(1): 191-192.

Loeuille, B., Keeley, S. C., Pirani, J. R., 2015. A phylogenetic analysis of Lychnophorinae (Asteraceae: Vernonieae): Based on molecular and morphological data. Syst. Bot. 40(1), 299315 .

Madhusudana Reddy, A., Suresh Babu, M. V., Prasad, K., 2018. Brachystelma vemanae. (Apocynaceae-Asclepiadoideae), a new species with completely reflexed corolla lobes and solitary flowers from Eastern Ghats, Andhra Pradesh, India. Nordic J. Bot. 36(10), e02067. Pp.1-4.

Manilal, K. S., Kumar, C. S., 2004. Orchid Memories A tribute to Gunnar Seidenfaden. Mentor Books, Calicut.

Mascarenhas, M. E., Janarthanam, M. K., 2010. A new variety of Rungia linifolia (Acanthaceae) from the Western Ghats of Karnataka, India. Novon. 20, 182-185.

Matthew, K.M., 1991. Precursory notes for the flora of Palni hills, South India. Kew Bull. 46(3), $539-546$.

Matthew, K. M., 1999. The flora of the Palni Hills, South India. The Rapinat Herbarium, Tiruchirapalli.

Meve, U., Liede, S., 2002. A molecular phylogeny and generic rearrangement of the stapelioid Ceropegieae (Apocynaceaea- Asclepiadoideae). Plant Syst. Evol. 234, 171-209.

Mishra, D. K., Singh, N. P., 2001. Endemic and threatened flowering plants of Maharashtra state. Botanical Survey of India, Calcutta.

Mostaph, M. K., Uddin, S. B., 2013. Dictionary of plant names of Bangladesh, Vasc. Pl. pp. 1-434. Janokalyan Prokashani, Chittagong, Bangladesh.

Nees von Esenbeck, C. G. D., 1847. Acanthaceae.
In: De Candolle, A. P. (Ed.), Prodromus Systematis Naturalis Regni Vegetabilis. Sumptibus Sociorum Treuttel \& Wurtz, Paris.

Ohashi, H., Ohashi, K., 2018. Grona, a genus separated from Desmodium (Leguminosae tribe Desmodieae). J. Jpn. Bot. 93(2), 104-120.

Pallithanam, J. M., 2001. A Pocket Flora of Sirumalai Hills, South India. The Rapinat Herbarium, St. Joseph's College, Tiruchirapalli.

Pandey, H.S., Dwarakan, P., 1995. Eria muscicola (Lindl.) Lindl. var. brevilinguis Joseph \& Chandrasekaran - A tiny orchid as new record for Tamil Nadu. J. Econ. Taxon. Bot. 19, 498500.

Paton, A., 1997. Classification and species of Plastoma and its relationship Haumaniastrum (Labiatae). Kew Bull. 52(2), 257-292.

POWO., 2019. Brachystelma. http://powo.science.kew.org/taxon/urn:lsid:ip ni.org:names: 331423-2 (accessed on 14 October 2019).

Prasad, K., Prasanna, P. V., 2016. Brachystelma seshachalamense (Apocynaceae), a new species from Andhra Pradesh, India. Bangl. J. Plant Taxon. 23(1), 53-57.

Prasad, K., Rao, B. R. P., 2013. Brachystelma nallamalayana sp. nov. (Apocynaceae: Asclepiadoideae: Ceropegieae) from India. J. Threat. Taxa. 5(14), 4904-4906.

Prasad, K., Venu, P., 2018. Rediscovery and notes on Brachystelma maculatum (Apocynaceae). Rheedea. 28(2), 73-77.

Prasad, K., Prasanna, P. V., Meve, U., Sankara Rao, M., Thulasaih, T., 2016. Brachystelma annamacharyae sp. nov. (Apocynaceae) from the Seshachalam hills of Andhra Pradesh (India). Nordic J. Bot. 34, 360-363.

Pridgeon, A. M., Cribb, P. J., Chase, M. C., Rasmussen, F. N., 2014. Genera Orchidacearum 6. Oxford University Press, New York, Oxford.

Pullaiah, T., Karuppusamy, S., Rama Murthy, K. S., 2019. Monograph on Brachystelma and Ceropegia in India. CRC press, Taylor \& Francis Group, Boca Raton.

Pullaiah, T., Sandhya Rani, S., Karuppusamy, S., 2011. Flora of Eastern Ghats: Hill ranges of South East India. Vol. 4, Regency Publications, New Delhi. 
Punekar, A. S., Vasudeva Rao, M. K., 2006. The genus Baccharoides Moench (Asteraceae) in India. J. Econ. Taxon. Bot. 30(3), 549-554.

Rajasekaran, K., 1986. Studies in Indian Loranthaceae-I. J. Swamy Bot. Club. 3(1-2), 15-18.

Ramachandran, V. S., Joseph, S., John, H. A., Sofiya, C., 2011. Caralluma bicolor sp. nov. (Apocynaceae, Asclepiadoideae) from India. Nordic J. Bot. 29, 447-450.

Rao, B. R. P., Prasad, K., Sadasivaiah, B., Basha, S. K., Babu, M. V. S., Prasanna, P. V., 2011. A new species of Brachystelma R.Br. (Apocynaceae: Asclepiadoideae - Ceropegieae) from India. Taiwania. 56, 223-226.

Rasingam, L., Chorghe, A., Meve, U., Rao, M. S., Prasanna, P. V., 2013. Brachystelma penchalakonense (Apocynaceae: Asclepiadoideae) - a new species from Andhra Pradesh, India. Kew Bull. 68, 663- 667.

Rasiya Beegam A., Sibi, M., 2012. Two new combinations in Acilepis (Asteraceae). Rheedea. 22(1), 38.

Reddy, C. S., 2001. Hybanthus vatsavayii (Violaceae): A new species from Andhra Pradesh, India. J. Econ. Taxon. Bot. 25, 219220.

Reddy, C. S., Raju, V. S., 2001. A new variety of Cleome chelidonii L.f. (Cleomaceae). J. Econ. Taxon. Bot. 25, 217-218.

Ridley H. N., 1888. A revision of the genera Microstylis and Malaxis. J. Linn. Soc. 24, 308351.

Robinson, H., Skvarla, J. J., 2006. Studies on the Gymnantheminae (Vernonieae: Asteraceae): restoration of the genus Monosis. Proc. Biol. Soc. Washington. 119, 600-607.

Rohwer, J. G., Li, J., Rudolph, B., Schmidt, S. A., van der Werff, H., Li, H.-W., 2009. Is Persea (Lauraceae) monophyletic? Evidence from nuclear ribosomal ITS sequences. Taxon. 58(4), 1153-1167.

Ruhsam, M., 2005. Survey of all the Rubiaceae specimens at the Royal Botanic Gardens, Kew.

Sadasivaiah, B., Kalpana, B., Narasimha, A., Sharath Goud, M., Babu Rao, N., 2016. Brachystelma nallamalayana K. Prasad \& B.R.P.Rao: A new distributional record for Telangana, India. Asian J. Plant Sci. Res. 6(2),
27-29.

Sanjappa, M., 1995. Revision of the genus Indigofera in India. Fasc. Fl. India 21. Botanical Survey of India, Howrah.

Sardesai, M. M., Kambale, S. S., Govekar, R. S., Kahalkar, V. I., 2016. Two new species of Brachystelma (Apocynaceae) from Peninsular India. Rheedea. 26(2), 142-149.

Sasidharan, N., 2013. Flowering plants of Kerala: CD ROM ver 2.0. Kerala Forest Research Institute, Peechi.

Schindler, A. K., 1927. Desmodii generumque affinium species et combinations novae. Feddes Repert. 23, 353-362.

Singh, P., Karthikeyan, K., Lakshminarasimhan, P., Dash, S.S., 2015. Endemic Vascular Plants of India. Botanical Survey of India, Kolkata, India.

Sirichamorn, Y., Adema, F. A., Roos, M. C., van Welzen, P. C., 2014. Molecular and morphological phylogenetic reconstruction reveals a new generic delimitation of Asian Derris (Fabaceae): Reinstatement of Solori and synonymisation of Paraderris with Derris. Taxon. 63(3), 522-538.

Sreemadhavan, C. P., 1967. Neesiella - A new genus of Acanthaceae. Phytologia 15: 270-271.

Tetali, P., Kulkarni, D. K., Tetali, S., Kumbhojkar, M. S., 1998. A new species of Brachystelma R.Br. (Asclepiadaceae) from Maharashtra, India. Rheedea. 8, 75-77.

Tirvengadum, D. D., 1978. Re-establishment of genus Catunaregam Wolf Rubiaceae: A contribution towards the plants described in Rheede's Hortus Malabaricus. Taxon. 27, 513517.

Turland, N. J., Wiersema, J. H., Barrie, F. R., Greuter, W., Hawksworth, D. L., Herendeen, P. S., Knapp, S., Kusber, W.-H., Li, D.-Z., Marhold, K., May, T. W., McNeill, J., Monro, A. M., Prado, J., Price, M. J., Smith, G. F., 2018. International Code of Nomenclature for algae, fungi, and plants (Shenzhen Code) adopted by the Nineteenth International Botanical Congress Shenzhen, China, July 2017. Regnum Vegetabile 159. Koeltz Botanical Books, Glashütten.

Vermeulen, J.J., Schuiteman, A., De Vogel, E.F., 2014. Nomenclatural changes in Bulbophyllum 
(Orchidaceae; Epidendroideae). Phytotaxa. 166(2), 101-113.

Vermeulen, J.J., Schuiteman, A., De Vogel, E.F., 2015. Corrections and an addition to Vermeulen et al. (2014): two new names and a new combination in Bulbophyllum (Orchidaceae; Epidendroideae; Malaxideae). Phytotaxa. 197(1), 59.

Vollesen, K., 2010. Justicia. In: Beentje, H. J., (Ed.), Flora of Tropical East Africa, Acanthaceae (Part 2). Royal Botanic Gardens, Kew, pp. 495-601.

Wadood Khan, M. A., 2014. Cyperaceae of the
Western Ghats, West Coast and Maharashtra. Dattsons Publishers, Nagpur.

Wahlert, G. A., Marcussen, T., de Paula-Souza, J., Feng, M., Ballard, H. E. Jr., 2014. A phylogeny of the Violaceae (Malpighiales) inferred from plastid DNA sequences: Implications for generic diversity and intrafamilial taxonomy. Syst. Bot. 39, 239-252.

Willdenow, C. L., 1803. Species Plantarum. Impensis Laurentii Salvii, Berlin.

Wood, J. R. I., 2010. New names and combinations in Indian Acanthaceae. Novon. 23(3), 385-395.

\section{How to cite this article:}

Kottaimuthu, R., Jothi Basu, M., Karmegam, N., 2019. Some new combinations and new names for Flora of India. Int. J. Curr. Res. Biosci. Plant Biol. 6(10), 33-46.

doi: https://doi.org/10.20546/ijcrbp.2019.610.004 